\title{
THE PRIORITY OF BEEF CATTLE FARM DEVELOPMENT STRATEGY IN SEMARANG REGENCY USING AHP AND SWOT (A'WOT) METHOD
}

\author{
SANTOSO BUDI ${ }^{1}$, PRASETIYONO BAMBANG WALUYO HADI EKO*2 AND PURNAWENI \\ HARTUTI $^{3}$
}

${ }^{1}$ Environmental Science, Diponegoro University, ${ }^{2}$ Faculty of Animal and Agricultural Sciences, Diponegoro University, Tembalang Campus, Semarang, 50275, Indonesia. ${ }^{3}$ Department of Public Administration, Faculty of Social and Political Sciences, Diponegoro University, Tembalang Campus, Semarang, 50139, Indonesia.

*Corresponding author: bambangwhep63@gmail.com

Submitted final draft: 21 January $2020 \quad$ Accepted: 19 March $2020 \quad$ http://doi.org/10.46754/jssm.2020.08.011

\begin{abstract}
The development of a directed and sustainable beef cattle farm can be achieved if the development strategy plan is based on existing real problems. This study aims to determine the priority of beef cattle farm development strategies in Semarang Regency, Central Java Province, Indonesia. The A'WOT method was applied in this study, by integrating strengths, weaknesses, opportunities, and threats (SWOT) and the Analytical Hierarchy Process (AHP). After determining the strengths, weaknesses, opportunities, and threats found in beef cattle farm business, group weights and SWOT factors were calculated using the AHP method, the results of which were the three priority strategies with the highest scores. These strategies can be summarised as follows: (1) optimising the utilisation of forage through silage and hay making, (2) optimising the provision of suitable land and meeting the technical requirements of livestock, and (3) optimising farmers' ability to access capital. It was concluded that sustainable beef cattle farm business in Semarang Regency could be improved through the application of priority strategies focusing on feed technology, land suitability, and access to capital. Findings also demonstrated that the A'WOT method is useful and effective in determining livestock sector strategies.
\end{abstract}

Keywords: Beef cattle, AHP, SWOT, sustainability livestock sector.

\section{Introduction}

Food security is a very important issue for Indonesia, given the nation's large and growing population. Fulfilling food needs is absolute, including the livestock sector. Cattle-farming in Indonesia is faced with very complex problems with unsustainable status (Syarifuddin, 2009; Sutanto \& Hendraningsih, 2011). Post 2000, the government has made various efforts to realise beef self-sufficiency. First, in 2000-2005 with a programme called the Beef Sufficiency Program, but it did not provide significant results. Secondly, in 2005-2010 with the Program to Accelerate Beef Self-Sufficiency Achievement, the results were also similar to the previous programme. Third, in 2010-2015 with the Independent Beef Support Program, it did not show maximum results (Paly et al., 2013; Ariningsih, 2014; Nuhung, 2015). The government keeps striving to achieve self-sufficiency in beef up to now. It includes encouraging increased community participation and investment in rural beef cattle farms (Suresti \& Wati, 2013).

Beef products are a source of protein, fat and some functional compounds that are important as food intake for humans. Not only for food but beef also has a close relationship with health, economy and culture (Pighin et al., 2016). Beef consumption is an effort to promote nutritional security in developing countries, such as in Indonesia. Demand for meat generally increases rapidly in developing countries (Thornton, 2010), along with the increasing welfare and lifestyle of the people. In Indonesia, it is estimated that in 2020 beef consumption will reach 3,36 kg per capita per year (Agus $\&$ Widi, 2018). The high public demand for beef is not accompanied by sufficient domestic production. There is a gap between demand and supply which is increasingly widening, where beef production only meets about $40 \%$ of the national demand for meat (Prasetiyono et al., 2007; Agus \& Widi, 2018). So far, most of the 
beef production in Indonesia (78\%) comes from traditional livestock. The shortfall is fulfilled by $22 \%$ of imports especially from Australia (Zakiah et al., 2017).

The low performance of the development of beef cattle farms as mentioned above also occurs in Semarang Regency. Beef cattle population has declined for three consecutive years, as evidenced by data (BPS Kabupaten Semarang, 2018) that the number of beef cattle is 53.135 (2014), 49.172 (2015) and 46.238 (2016). The decline in livestock population is caused by various factors, both technical and non-technical, such as issues of policy, management, and coordination between stakeholders. Government policies that are less effective are the upstream of the low performance of the development of beef cattle farms (Nuhung, 2015). Effective policies must be preceded by comprehensive strategic planning. However, the beef cattle farm development strategy that has been compiled so far has in fact not provided optimal results, or in other words, the policies implemented have not been in line with expectations (Mulyo et al., 2012).

Many studies reported that the low performance of livestock development in Indonesia is due to the lack of farmer involvement in the policy planning process (Iqbal, 2007), whereas beef cattle business is dominated by traditional farmers, most of whom are not accompanied by adequate capital and management (Malotes, 2016). Farmers only become the object or recipient not the subject of the programme and as a result the policies applied are less acceptable. Decision making regarding the right strategy for the development of beef cattle farming is indeed difficult due to various criteria or factors (such as environmental, economic, social) and multi-stakeholders.

Analysis of strengths, weaknesses, opportunities, and threats (SWOT) has been the main framework in the process of formulating development strategies in various sectors (Arslan \& Er, 2008; Helms \& Nixon, 2010; Akbulak $\&$ Cengiz, 2014). Integrating SWOT with the analytical hierarchy process (AHP) method known as A'WOT makes it possible to achieve more analytical results, providing significant improvements in the process of decision making and public acceptance (Kajanus et al., 2004; Huang et al., 2011; Akbulak \& Cengiz, 2014; Alitaneh \& Golsheykhi, 2015). This study aims to determine the priority of beef cattle farm development strategies in Semarang Regency using the A'WOT method.

\section{Materials and Methods}

This study uses a combined method (qualitativequantitative). The location of the study was in the area of Semarang Regency, Central Java Province, Indonesia. The maintenance pattern of beef cattle that is often found in the research area is an intensive maintenance. The majority of the population are traditional farmers with $<10$ head of beef cattle, while large-scale livestock (feedlot) with livestock raising >500 animals are only found in two sub-districts, namely: Getasan, and Ungaran Barat. Figure 1 shows the location of the study.

The integration of the SWOT and AHP methods known as A'WOT was used in this study. The factors that influence the development of beef cattle farms in Semarang Regency are described in detail through determining their current strengths and weaknesses, opportunities that arise, and possible threats. The preparation of each factor that is included in the internal and external groups in the SWOT method is the result of literature studies and preliminary interviews with the farmers, the results of which are then discussed. The assessment was made of the importance level of using the AHP method by policy makers as experts. Version 11 software Expert Choice was used to facilitate calculations in this analysis.

The purposive sampling technique, also called judgment sampling, is the deliberate choice of an informant due to the qualities the informant possesses. It is not a non-random technique that does not need underlying theories or a set number of informants (Tongco, 2007). Key informants became very important 


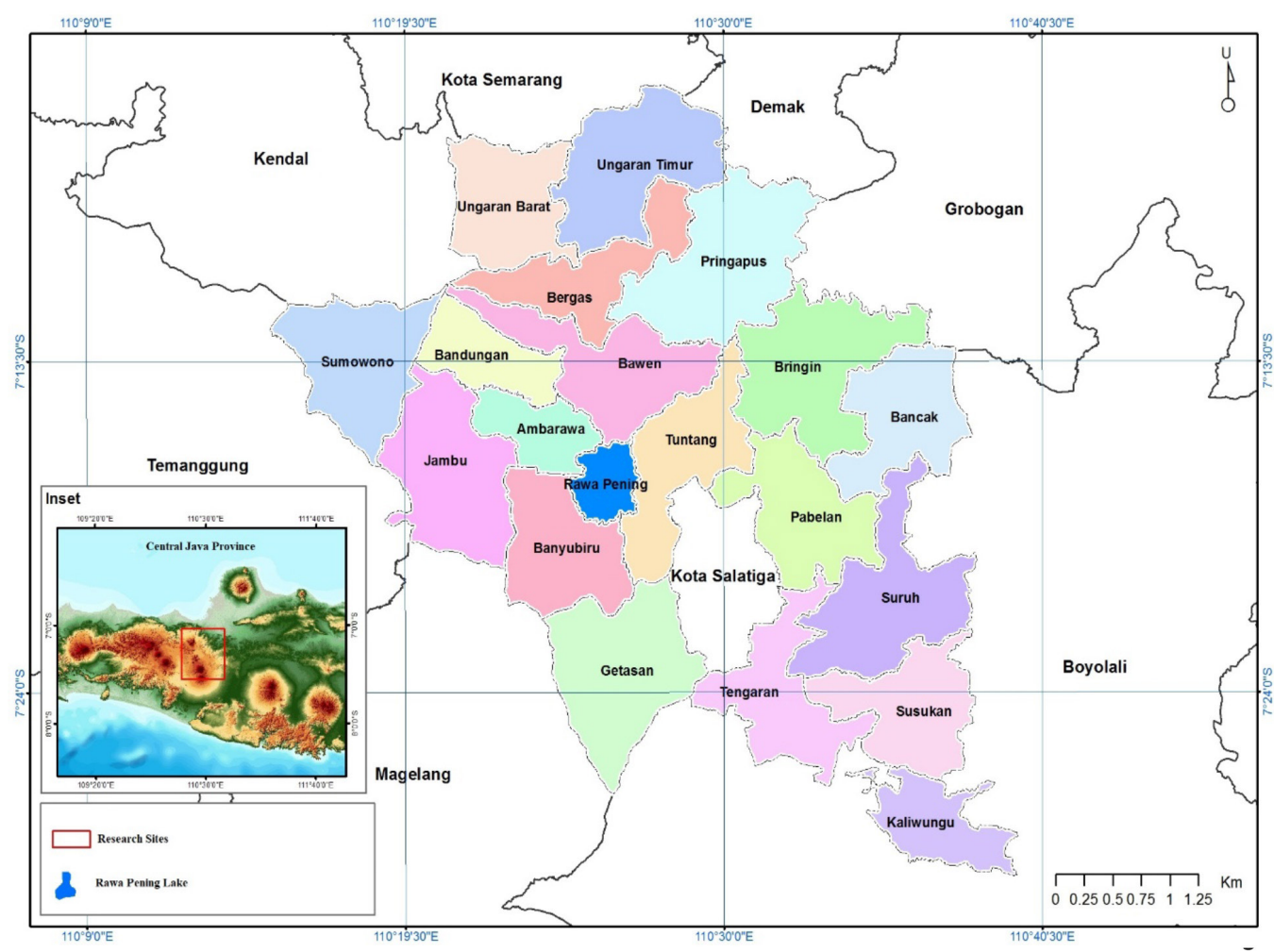

Figure 1: Study area in Semarang Regency, Central Java Province, Indonesia

guidelines as guides or providers of information needed by researchers (Claire Jarvis et al., 2004; Lyon \& Hardesty, 2005; Cruz García, 2006). The selected informants were policy makers (experts) because they were able to provide a better focus or understanding regarding the problems faced (Aydiner et al, 2016) especially in developing beef cattle farms.

There are 4 informants, each of whom was from: (1) Animal Husbandry and Animal Health Service of Central Java Province, Indonesia (2) Regional Planning, Research and Development Agency of Semarang Regency, Indonesia (3) Agriculture, Fisheries and Food Agency of Semarang Regency, Indonesia and (4) Lecturer of Faculty Animal Husbandry and Agriculture, Diponegoro University, Indonesia. A detailed description of how the A'WOT method was applied is further described in the following section.

\section{Weights Allocation of Group and SWOT Factors Using the AHP Method}

Weights of group and SWOT factors were determined by considering the level of influence on the development of beef cattle farms. Weight reflects the relative importance of each factor and therefore must be chosen carefully (Mishra et al., 2015). The weight of all SWOT factors was determined using the Analytic Hierarchy Process (AHP) method.

\section{Application of the Analytic Hierarchy Process (AHP) Method}

AHP method is based on hierarchy making to analyse complex and multi-criteria problems (Saaty, 1980; 2008). AHP analysis can be applied in various fields such as project management, strategy planning, and the selection of policy alternatives (Giri \& Nejadhashemi, 2014), including in the beef cattle farming sector. AHP is considered to be able to provide effective 
solutions for decision making by determining the relative priorities of the criteria or proposed factors (Ishizaka \& Labib, 2011). Policy makers (experts) assess each factor using a pairwise comparison matrix, based on the scale shown on Table 1. The principle of AHP analysis is to use numerical techniques to obtain quantitative values from verbal comparisons conducted (Kurttila et al., 2000).

Table 1: AHP fundamental scale

\begin{tabular}{cc}
\hline $\begin{array}{c}\text { Intensity of } \\
\text { Interest }\end{array}$ & Definition \\
\hline 1 & Equal \\
3 & Moderate \\
5 & Strong \\
7 & Very strong \\
9 & Extreme important \\
$2,4,6,8$ & Middle value between two \\
& adjacent values \\
\hline
\end{tabular}

Source: (Saaty, 1980; 2008).

Through pairwise comparison, AHP is able to calculate weights for each factor by taking the largest eigenvector of the order $\mathrm{n}$ matrix (Feizizadeh et al., 2014). The matrices are generally reciprocal, expressed mathematically as: $n(n-1) / 2$, comparisons are made for $n$ number of elements in pairwise comparison matrices (Akinci et al., 2013). After pairwise comparison matrices are made, the eigenvectors or normalised weight factors (Saaty, 1980; 2008) are calculated. AHP is able to identify inconsistent perception given by experts. This is one of the advantages of the AHP method (García et al., 2014). Consistency ratio (CR) is a benchmark or the magnitude of acceptable values from expert perceptions (Chen et al., 2010; Park et al., 2011), shown in equation (1). The magnitude of the CR value depends on the consistency index value $(\mathrm{CI})$ and random inconsistency (RI), shown in equation (2).

$$
\begin{aligned}
& \mathrm{CR}=\frac{\mathrm{CI}}{\mathrm{RI}} \\
& \mathrm{CI}=\frac{\lambda \max -n}{n-1}
\end{aligned}
$$

Equation (2) represents the CI value, where $\lambda$ max is the maximum eigenvalue of the pairwise comparison matrix, and $\mathrm{n}$ is the number of factors found in each matrix. RI is an inconsistency ratio value, depending on the order of the matrix specified by Saaty (1980) shown in Table 2. If the CR value is $>10 \%$ or 0.1 then the expert judgment must be repeated or improved. Conversely, if the CR value is $<0.1$, the assessment results are declared valid and consistent.

\section{Priority Strategy for Developing Beef Cattle Farms in Semarang Regency}

Each policy maker (expert) has quantitative values from the group and SWOT factors through the AHP method. Each perception from the expert is then combined using a geometric average (equation 3), resulting in a joint assessment. This combined assessment produces new weights for each group and SWOT factors (Saaty, 2008).

$$
\mathrm{GM}=\sqrt[\mathrm{n}]{(\mathrm{X} 1)(X 2) \ldots(X n)}
$$

GM is a geometric average and $\mathrm{X}$ is the value of each factor in a pairwise comparison matrix (scale 1-9). Definition X1 is the first expert, X2 is the second expert, $\mathrm{Xn}$ is the nth expert, and $\mathrm{n}$ is the number of informants (experts) who carry out the assessment.

Determination of priority strategies is carried out by considering the results of a joint assessment of experts. The group weight is

Table 2: Random inconsistencies (RI)

\begin{tabular}{ccccccccccc}
\hline Matrix Order (n) & $\mathbf{1}$ & $\mathbf{2}$ & $\mathbf{3}$ & $\mathbf{4}$ & $\mathbf{5}$ & $\mathbf{6}$ & $\mathbf{7}$ & $\mathbf{8}$ & $\mathbf{9}$ & $\mathbf{1 0}$ \\
\hline RI & 0 & 0 & 0.58 & 0.9 & 1.12 & 1.24 & 1.32 & 1.41 & 1.46 & 1.49 \\
\hline
\end{tabular}

Source: (Saaty, 1980; 2008) 
multiplied by the weight of each SWOT factor resulting in global weights. The global weight with the highest value is used as the priority of the proposed development strategy to be applied.

\section{Results}

Based on the SWOT analysis, there are a total of sixteen factors that influenced the development of beef cattle farms in Semarang Regency. Each group of strengths, weaknesses, opportunities, and threats was composed of 4 factors in it (Table 3). A joint assessment of policy makers (experts) who considered group weight and SWOT factors is shown in (Table 4).

The weight of the SWOT results from the perceptions of all experts combined with geometric averages (Table 4) show that the

Table 3: SWOT factors for development of beef cattle farming in Semarang Regency

\begin{tabular}{ll}
\hline \multicolumn{1}{c}{ Strengths } & \multicolumn{1}{c}{ Weaknesses } \\
\hline Availability of forage (S1) & Low quality fodder (W1) \\
\hline Availability of beef cattle land (S2) & Capital limitations (W2) \\
\hline $\begin{array}{l}\text { Potential marketing of livestock products } \\
\text { (S3) }\end{array}$ & $\begin{array}{l}\text { The spread of livestock officers is uneven } \\
\text { (W3) }\end{array}$ \\
\hline $\begin{array}{l}\text { Availability of business development } \\
\text { supporting facilities (S4) }\end{array}$ & $\begin{array}{l}\text { The quality of farmers and farmer groups } \\
\text { is limited (W4) }\end{array}$ \\
\hline $\begin{array}{ll}\text { Opportunities } \\
\text { High demand for beef (O1) }\end{array}$ & $\begin{array}{l}\text { Marketing and trading system (T1) } \\
\text { The trend of rising beef prices (O2) }\end{array}$ \\
\hline $\begin{array}{l}\text { The livestock industry infrastructure is } \\
\text { quite adequate (O3) }\end{array}$ & $\begin{array}{l}\text { The role of large farmers (feedloters) is } \\
\text { limited (T3) }\end{array}$ \\
\hline Beef self-sufficiency policy (O4) & Land conversion (T4) \\
\hline
\end{tabular}

Table 4: Group and SWOT factor weights

\begin{tabular}{|c|c|c|c|c|c|}
\hline $\begin{array}{l}\text { SWOT } \\
\text { Group }\end{array}$ & $\begin{array}{l}\text { Group } \\
\text { Weight }\end{array}$ & $\begin{array}{l}\text { SWOT } \\
\text { Factor }\end{array}$ & $\begin{array}{l}\text { Factor } \\
\text { Weight }\end{array}$ & CR & $\begin{array}{c}\text { Global Factor } \\
\text { Weight }\end{array}$ \\
\hline \multirow[t]{4}{*}{ Strengths } & \multirow[t]{4}{*}{0.4} & Availability of forage & 0.356 & \multirow[t]{4}{*}{0.01} & 0.142 \\
\hline & & $\begin{array}{l}\text { Availability of beef cattle land } \\
\text { Potential marketing of livestock }\end{array}$ & 0.352 & & 0.141 \\
\hline & & products & 0.092 & & 0.037 \\
\hline & & $\begin{array}{l}\text { Availability of business } \\
\text { development supporting facilities }\end{array}$ & 0.2 & & 0.08 \\
\hline \multirow[t]{4}{*}{ Weaknesses } & \multirow[t]{4}{*}{0.255} & Low quality fodder & 0.292 & \multirow[t]{4}{*}{0.01} & 0.074 \\
\hline & & Capital limitations & 0.366 & & 0.093 \\
\hline & & $\begin{array}{l}\text { The spread of livestock officers is } \\
\text { uneven }\end{array}$ & 0.101 & & 0.026 \\
\hline & & $\begin{array}{l}\text { The quality of farmers and farmers } \\
\text { groups is limited }\end{array}$ & 0.241 & & 0.061 \\
\hline \multirow[t]{4}{*}{ Opportunities } & \multirow[t]{4}{*}{0.107} & High demand for beef & 0.232 & \multirow[t]{4}{*}{0.03} & 0.025 \\
\hline & & The trend of rising beef prices & 0.105 & & 0.011 \\
\hline & & $\begin{array}{l}\text { The livestock industry } \\
\text { infrastructure is quite adequate }\end{array}$ & 0.267 & & 0.028 \\
\hline & & Beef self-sufficiency policy & 0.396 & & 0.042 \\
\hline \multirow[t]{4}{*}{ Threats } & \multirow[t]{4}{*}{0.238} & Marketing and trading system & 0.316 & \multirow[t]{4}{*}{0.004} & 0.075 \\
\hline & & Environmental pollution issues & 0.127 & & 0.03 \\
\hline & & $\begin{array}{l}\text { The role of large farmers } \\
\text { (feedloters) is limited }\end{array}$ & 0.358 & & 0.085 \\
\hline & & Land conversion & 0.199 & & 0.047 \\
\hline
\end{tabular}


SWOT group with the highest priority is the strength group (40\%) followed by the weakness group $(25.5 \%)$, the threat group $(23.8 \%)$, and the opportunity groups $(10.7 \%)$. Policy makers (experts) agreed to further optimise the strength of the Semarang Regency region in supporting the development of beef cattle farms.

Based on Table 4, it is known that the highest priority factor in the 'strength' group is the availability of forage $(35.6 \%)$. The highest priority in the 'weakness' group is the factor of limited capital $(36.6 \%)$. The government policy factor for self-sufficiency in beef is the highest priority $(39.6 \%)$ in the 'opportunity' group. Meanwhile, the limited role of large-scale farms (feedloters) is the highest priority $(35.8 \%)$ in the 'threat' group.

The strategy for developing beef cattle farm is determined based on the highest global weight. The global weight of the SWOT factor which occupies the top three (Table 4) includes: availability of forage $(14.2 \%)$, availability of beef cattle land (14.1\%), and capital limitation (9.3\%). The proposed strategy and scope are summarised below and shown in Figure 2.
The first strategy was to optimise the natural resource potential of Semarang Regency. The most important potential of natural resources for beef cattle farming is the availability of forage as animal feed. Forage production in each sub-district must be calculated so that estimates of the beef cattle population that can be accommodated in the region are known. The fact is that the production of fiber (grass) feed is abundant during the rainy season, but is difficult for farmers to obtain during the dry season. Preserving fresh forages through the manufacture of silage or hay can be one solution to overcome the problem of lack of fresh forage in the dry season.

Silage is a forage preservation product through the effect of acidity by anaerobic fermentation process. The principle of making silage is forage fermentation by microbes that produce a lot of lactic acid. Lactic acid produced during the fermentation process will act as a preservative so it can suppress the growth of decomposing microorganisms (Naif et al., 2016). Making silage is intended to optimise the preservation of nutrient content found in

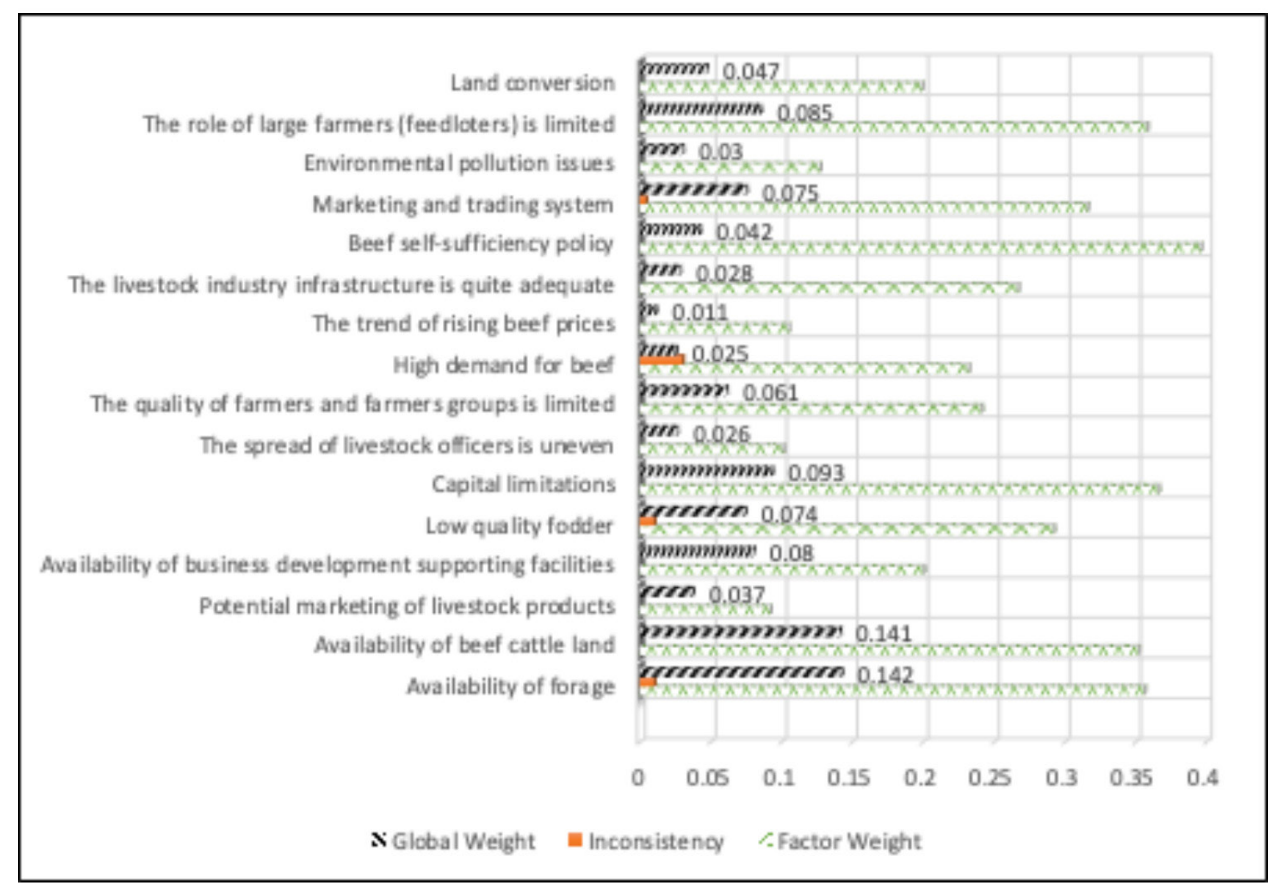

Figure 2: Priority strategy for the development of beef cattle farm in Semarang Regencyx 
forages or even to improve its quality (Khan et al., 2004). The advantages of making silage are longer shelf life, easier to digest livestock, and more carotene content in the forage. Carotene compounds are also known to increase animal fertility.

Hay is a forage preserved by drying, aiming to reduce the water content so that it reduces the activity of fungi, bacteria and enzymes which negatively affect the quality of forage. Hay production aims to minimise the loss of dry matter to provide fodder contains good nutrient. Making hay from grass is best and profitable to be applied in the tropics because the forage drying can be done naturally using sunlight (Sirait, 2017). Hay has even been very commonly used as animal feed in countries with four seasons, when fodder cannot be obtained during winter. Hay as forage has several forms such as long hay, cubed hay, baled hay, and shredded hay.

Research on alternative feed sources for beef cattle by utilising agricultural, plantation and food industry waste has been carried out by many universities and research institutions. The nutrition quality of agricultural and plantation waste can be improved through fermentation, supplementation, and manufacturing of complete feed. The results of these studies need to be socialized to farmers so that they are able to apply them in the field to increase the production and productivity of cultivated beef cattle.

The second strategy is to provide suitable land and meet the technical requirements of livestock. The government must ensure the availability of land for beef cattle farms, including land status that must be clear and have legality. One effort that can be made to realise this is the local government conducts a potential and appropriate land inventory for the development of beef cattle farms equipped with maps, the condition of available infrastructure, including the availability of water sources. These suitable and available lands are then offered to investors by a mechanism and system that guarantees the ease of investment.
The development of beef cattle farms should be directed to the development of medium to large scale farms (feedlot). Feedlot is a driver for the development of traditional livestock because it is able to meet the economy scale of cattle business. If the economy scale is fulfilled, then there will be efficiency and optimisation of resource use, so that the result will encourage the increase of domestic beef products competitiveness. Investment in the development of beef cattle farms can be carried out from upstream to downstream such as: in the field of nurseries (through the construction of breeding farms), in the field of livestock cultivation (building feedlot and slaughterhouses), as well as in the feed and pharmaceutical industries (development of fodder processing industry). Flexible government policies will determine the success of the development of beef cattle farming industry, especially if it involves the business world that requires business certainty and a conducive business climate (Nuhung, 2015).

The third strategy is to increase the ability of farmers to access capital or financing. Traditional farmers are small scale farmers with limited maintenance of beef cattle due to limited business capital. Farmers have low access to banks, both because of their ignorance and because of banking policies that have not fully aligned with these farmers. Traditional farmers need to be encouraged to become commercial farmers that are integrated with the market. One effort that can be done is through the application of a plasma core development pattern.

The plasma core philosophy is to integrate small businesses (traditional farmers) with big entrepreneurs (investors). Farmers have land, labour, experience in raising beef cattle, and can provide cattle cage, but on the other hand have limited capital, technology, market access, and access to information. While investors find it difficult to find land to meet the scale of business, and difficulties in providing labour, they have strengths in the aspects that are the limitations of traditional farmers. Through collaboration between the two, strong synergy 
is formed. The plasma core pattern is able to encourage and motivate traditional farmers to develop their businesses so that production capacity becomes greater. The government functions as a facilitator, coach, and controller so that the pattern of cooperation can develop as planned. The development of beef cattle farms with plasma core patterns will form a cattle farm agribusiness area which is a regional development model (Muslim, 2006).

\section{Discussion}

Nowadays, the Indonesian government keeps striving to achieve self-sufficiency in beef considering that public consumption is increasing every year. The development of beef cattle farms in potential areas is being increasingly intensified. Semarang Regency is one of the areas in Central Java Province that has the potential to develop beef cattle farms because it has abundant natural resources in the form of land for livestock cultivation and land for growing forage. Determination of effective livestock development strategies is important so that the potential in the region can be utilised sustainably.

Analysis of strengths, weaknesses, opportunities, and threats (SWOT) is a method that can be used to determine accurate strategies, including in the beef cattle sector (Wasike et al., 2011; Martín-Collado et al., 2013) in Semarang Regency in particular, and in Indonesia in general. Substantially, SWOT does offer advantages in determining strategy, but there are some disadvantages in terms of a more comprehensive evaluation. SWOT cannot establish strategic weights for selected alternatives (Kangas et al., 2003; Masozera et al., 2006; Yüksel \& Dağdeviren, 2007; Kajanus et al., 2012; Abdel-Basset et al., 2018), in addition to that, its measurement dimension is inadequate which results to arising of uncertainty (Shrestha et al., 2004; Shinno et al., 2006). SWOT assessment is better when the proposed factors are assessed comparatively, not judged separately.
Weaknesses in SWOT analysis can be minimised through integration with one type of multi-criteria decision analysis (MCDA), namely the analytical hierarchy process method (I. Linkov et al., 2006; 2009). AHP is widely used in research because it is easily understood and applied for accurate decision making on a large scale. The AHP method is able to handle quantitative and qualitative criteria, factors in the SWOT analysis can be considered more accurate and detailed. The principle of the AHP method is to use numerical techniques to obtain quantitative values from verbal comparisons made (Kurttila et al., 2000). AHP and SWOT integration, hereinafter referred to as A'WOT, enable policy makers (experts) to assess the factors proposed in greater depth through pairwise comparison techniques (Akbulak \& Cengiz, 2014; Feizizadeh et al., 2014; García et al., 2014). With the A'WOT method, measurable and comparable characters are given to all SWOT factors so that a more logical evaluation of all alternative strategies can be achieved.

This study uses the A'WOT method to determine the priority of beef cattle farm development strategies in Semarang Regency. The condition of beef cattle farms in the study area is seen based on the strengths, weaknesses, opportunities, and threats that exist. Three priority livestock development strategies are produced, believed to be able to contribute to the sustainability of beef cattle farms. Furthermore, the AWOT method is a useful and effective method for multi-criteria decision making in various sectors, including the livestock sector.

\section{Conclusion}

The results of the study stated that the proposed priority of beef cattle farm strategies in Semarang Regency included: (1) optimising the utilisation of forage livestock through silage and hay making, (2) optimising the provision of suitable land and meeting livestock technical requirements, and (3) optimising the ability of farmers to access capital or financing. By considering the strategy produced, it is expected that the results of this study can help local 
governments in planning a more sustainable beef cattle farming policy, especially in the Semarang Regency area.

\section{Acknowledgements}

The authors highly appreciate the valuable comments of Dr. Ir. Bambang Waluyo Hadi Eko Prasetiyono, M.S., M.Agr and Dr. Hartuti Purnaweni, MPA on the initial draft of the manuscript. The authors are also grateful to the informants for participating in the survey.

\section{References}

Abdel-Basset, M., Mohamed, M., \& Smarandache, F. (2018). An extension of Neutrosophic AHP-SWOT Analysis for strategic planning and decision-making. Symmetry, 10(4). https://doi.org/10.3390/ sym 10040116

Agus, A., \& Widi, T. S. M. (2018). Current situation and future prospects for beef cattle production in Indonesia - A review. Asian-Australasian Journal of Animal Sciences, 31(7), 976-983. https://doi. org/10.5713/ajas.18.0233

Akbulak, C., \& Cengiz, T. (2014). Determining ecotourism strategies using A'WOT Hybrid Method: Case study of Troia Historical National Park, Çanakkale, Turkey. International Journal of Sustainable Development and World Ecology, 21(4), 380-388. https://doi.org/ 10.1080/13504509.2014.903383

Akinci, H., Özalp, A. Y., \& Turgut, B. (2013). Agricultural land use suitability analysis using GIS and AHP technique. Computers and Electronics in Agriculture, 97, 71-82. https://doi.org/10.1016/j. compag.2013.07.006

Alitaneh, S., \& Golsheykhi, M. (2015). Applying the AHP Model in estimation of Holstein Dairy Cows sperms using in farms: An different research in animal science. Global Journal of Animal Scientific Research, 3(1), 253-263.
Ariningsih, E. (2014). Performance of national beef self-sufficiency policy. Forum Penelitian Agro Ekonomi, 32(2), 137-156.

Arslan, O., \& Er, I. D. (2008). SWOT Analysis for safer carriage of bulk liquid chemicals in tankers. Journal of Hazardous Materials, 154(1-3), 901-913. https://doi. org/10.1016/j.jhazmat.2007.10.113

Aydiner, C., Sen, U., Koseoglu-Imer, D. Y., \& Can Dogan, E. (2016). Hierarchical prioritization of Innovative Treatment Systems for sustainable dairy wastewater management. Journal of Cleaner Production, 112, 4605-4617. https://doi. org/10.1016/j.jclepro.2015.08.107

BPS Kabupaten Semarang. (2018). Kabupaten semarang dalam angka. Semarang: Badan Pusat Statistik Kabupaten Semarang.

Chen, Y., Yu, J., \& Khan, S. (2010). Spatial sensitivity analysis of multi-criteria weights in GIS-based land suitability evaluation. Environmental Modelling and Software, 25(12), 1582-1591. https://doi. org/10.1016/j.envsoft.2010.06.001

Claire Jarvis, M., Marie Miller, A., Sheahan, J., Ploetz, K., Ploetz, J., Ready Watson, R., ... Orrs, B. (2004). Edible wild mushrooms of the Cofre De Perote Region, Veracruz, Mexico: An ethnomycological study of common names and uses. Economic Botany, 58, 111-115. https://doi. org/10.1663/0013-0001(2004)58[S111:E WMOTC]2.0.CO;2

Cruz García, G. S. (2006). The mother - Child nexus. Knowledge and valuation of wild food plants in Wayanad, Western Ghats, India. Journal of Ethnobiology and Ethnomedicine, 2(39), 1-6. https://doi. org/10.1186/1746-4269-2-39

Feizizadeh, B., Jankowski, P., \& Blaschke, T. (2014). A GIS based spatially-explicit sensitivity and uncertainty analysis approach for multi-criteria decision analysis. Computers and Geosciences, 64, 81-95. https://doi.org/10.1016/j. cageo.2013.11.009 
García, J. L., Alvarado, A., Blanco, J., Jiménez, E., Maldonado, A. A., \& Cortés, G. (2014). Multi-attribute evaluation and selection of sites for agricultural product warehouses based on an analytic hierarchy process. Computers and Electronics in Agriculture, 100, 60-69. https://doi.org/10.1016/j. compag.2013.10.009

Giri, S., \& Nejadhashemi, A. P. (2014). Application of analytical hierarchy process for effective selection of agricultural best management practices. Journal of Environmental Management, 132, 165-177. https://doi.org/10.1016/j. jenvman.2013.10.021

Helms, M. M., \& Nixon, J. (2010). Exploring SWOT Analysis - Where are we now? A review of academic research from the last decade. Journal of Strategy and Management, 3. https://doi. org/10.1108/17554251011064837

Huang, I. B., Keisler, J., \& Linkov, I. (2011). Multi-criteria decision analysis in environmental sciences: Ten years of applications and trends. Science of the Total Environment, 409(19), 3578-3594. https://doi.org/10.1016/j. scitotenv.2011.06.022

Iqbal, M. (2007). Analisis peran pemangku kepentingan dan implementasinya dalam pembangunan pertanian. Jurnal Litbang Pertanian, 26(3), 89-99. Retrieved from http://pustaka.litbang.pertanian.go.id/ publikasi/p3263071.pdf

Ishizaka, A., \& Labib, A. (2011). Review of the main developments in the Analytic Hierarchy Process. Expert Systems with Applications, 38(11), 14336-14345. https://doi.org/10.1016/j. eswa.2011.04.143

Kajanus, M., Kangas, J., \& Kurttila, M. (2004). The use of value focused thinking and the A'WOT Hybrid Method in tourism management. Tourism Management, 25(4), 499-506. https://doi.org/10.1016/ S0261-5177(03)00120-1
Kajanus, M., Leskinen, P., Kurttila, M., \& Kangas, J. (2012). Making use of MCDS Methods in SWOT AnalysisLessons learnt in Strategic Natural Resources Management. Forest Policy and Economics, 20, 1-9. https://doi. org/10.1016/j.forpol.2012.03.005

Kangas, J., Kurttila, M., Kajanus, M., \& Kangas, A. (2003). Evaluating the management strategies of a forestland estate - The S-O-S approach. Journal of Environmental Management, 69(4), 349-358. https://doi. org/10.1016/j.jenvman.2003.09.010

Khan, M. A., Sarwar, M., \& Khan, M. M. S. (2004). Feeding value of urea treated corncobs ensiled with or without enzose (Corn Dextrose) for lactating crossbred cows. Asian-Australasian Journal of Animal Sciences, 17, 1093-1097.

Kurttila, M., Pesonen, M., Kangas, J., \& Kajanus, M. (2000). Utilizing the Analytic Hierarchy Process (AHP) in SWOT Analysis - A Hybrid Method and its application to a forest-certification case. Forest Policy and Economics, 1(1), 41-52. https://doi.org/10.1016/S13899341(99)00004-0

Linkov, I., Satterstrom, F. K., Kiker, G., Batchelor, C., Bridges, T., \& Ferguson, E. (2006). From comparative risk assessment to multi-criteria decision analysis and adaptive management: Recent developments and applications. Environment International, 32(8), 1072-1093. https://doi.org/10.1016/j. envint.2006.06.013

Linkov, Igor, Loney, D., Cormier, S., Satterstrom, F. K., \& Bridges, T. (2009). Weight-of-evidence evaluation in environmental assessment: Review of qualitative and quantitative approaches. Science of the Total Environment, 407(19), 5199-5205. https://doi.org/10.1016/j. scitotenv.2009.05.004

Lyon, L. M., \& Hardesty, L. H. (2005). Traditional healing in the contemporary 
life of the antanosy people of Madagascar. Ethnobotany Research \& Applications, 3, 287-294. https://doi.org/10.17348/ era.3.0.287-294

Malotes, J. (2016). Strategi pengembangan usaha peternakan sapi potong di Kecamatan Tinangkung Utara, Kabupaten Banggai Kepulauan. Agroland, 23(3), 198-207.

Martín-Collado, D., Díaz, C., Mäki-Tanila, A., Colinet, F., Duclos, D., Hiemstra, S. J., \& Gandini, G. (2013). The use of SWOT Analysis to explore and prioritize conservation and development strategies for local cattle breeds. Animal, 7(6), 885-894. https://doi.org/10.1017/ S175173111200242X

Masozera, M. K., Alavalapati, J. R. R., Jacobson, S. K., \& Shrestha, R. K. (2006). Assessing the suitability of communitybased management for the Nyungwe Forest Reserve, Rwanda. Forest Policy and Economics, 8(2), 206-216. https:// doi.org/10.1016/j.forpol.2004.08.001

Mishra, A. K., Deep, S., \& Choudhary, A. (2015). Identification of suitable sites for organic farming using AHP \& GIS. Egyptian Journal of Remote Sensing and Space Science, 18(2), 181-193. https:// doi.org/10.1016/j.ejrs.2015.06.005

Mulyo, Marzuki, \& Imam, S. S. (2012). Analisis kebijakan pemerintah mengenai budidaya sapi potong di Kabupaten Semarang. Animal Agriculture Journal, 1(2), 266277.

Muslim, C. (2006). Pengembangan Sistem Integrasi Padi-Ternak dalam Upaya Pencapaian Swasembada Daging di Indonesia: Suatu tinjauan evaluasi. Analisis Kebijakan Pertanian, 4. Bogor.

Naif, R., Oktovianus, \& Agung, A. (2016). Kualitas nutrisi Silase Rumput Gajah (Pennisetum Purpureum) yang diberi dedak padi dan jagung giling dengan level berbeda. Journal of Animal Science, 1(1), 6-8.
Nuhung, I. A. (2015). Kinerja, kendala, dan strategi pencapaian swasembada daging sapi. Forum Penelitian Agro Ekonomi, 33(1), 63-80.

Paly, B., Natsir, A., Rasyid, S., \& Fahmid, I. M. (2013). Interconnectivity multi criteria for sustainable development of beef cattle. International Journal of Scientific \& Technology Research, 2(7), 115-121.

Park, S., Jeon, S., Kim, S., \& Choi, C. (2011). Prediction and comparison of urban growth by land suitability index mapping using GIS and RS in South Korea. Landscape and Urban Planning, 99(2), 104-114. https://doi.org/10.1016/j. landurbplan.2010.09.001

Pighin, D., Pazos, A., Chamorro, V., Paschetta, F., Cunzolo, S., \& Grigioni, G. (2016). A contribution of beef to human health: A review of the role of the animal production systems. The Scientific World Journal.

Prasetiyono, B. W. H. E., Suryahadi, Toharmat, T., \& Syarief, R. (2007). Strategi suplementasi protein ransum sapi potong berbasis jerami dan dedak padi. Media Peternakan, 30(3), 207-217.

Saaty, T. L. (1980). The analytic hierarchy process. New York: McGraw Hill.

Saaty, T. L. (2008). Decision making with the analytic hierarchy process. International Journal of Services Sciences, 1(1), 83-98. https://doi.org/10.1504/ IJSSCI.2008.017590

Shinno, H., Yoshioka, H., Marpaung, S., \& Hachiga, S. (2006). Quantitative SWOT Analysis on global competitiveness of machine tool industry. Journal of Engineering Design, 17(3), 251-258. https://doi. org/10.1080/09544820500275180

Shrestha, R. K., Alavalapati, J. R. R., \& Kalmbacher, R. S. (2004). Exploring the potential for Silvopasture Adoption in South-Central Florida: An application of SWOT-AHP method. Agricultural 
Systems, 81(3), 185-199. https://doi. org/10.1016/j.agsy.2003.09.004

Sirait, J. (2017). Rumput Gajah Mini sebagai Hijauan Pakan untuk Ruminansia. WARTAZOA, 27(4), 167-176.

Suresti, A., \& Wati, R. (2013). Strategi pengembangan usaha peternakan sapi potong di Kabupaten Pesisir Selatan. Jurnal Peternakan Indonesia, 14(1), 249262.

Sutanto, A., \& Hendraningsih, L. (2011). Analisis keberlanjutan usaha sapi perah di Kecamatan Ngantang, Kabupaten Malang. Gamma, 7(1), 1-12.

Syarifuddin, H. (2009). Indeks keberlanjutan integrasi tanaman dengan ternak (Crop Livestock System) di Kuamang Kuning. Jurnal Ilmiah Ilmu-Ilmu Peternakan, XII(1), 41-49.

Thornton, P. K. (2010). Livestock production: Recent trends, future prospects. Philosophical Transactions of the Royal Society B: Biological Sciences, 365(1554), 2853-2867. https://doi.org/10.1098/rstb. 2010.0134
Tongco, M. D. C. (2007). Purposive sampling as a tool for informant selection. Ethnobotany Research \& Applications, 5, 147-158. https://doi.org/10.17348/era.5.0.147-158

Wasike, C. B., Magothe, T. M., Kahi, A. K., \& Peters, K. J. (2011). Factors that influence the efficiency of Beef and Dairy Cattle Recording System in Kenya: A SWOTAHP Analysis. Tropical Animal Health and Production, 43(1), 141-152. https:// doi.org/10.1007/s11250-010-9666-3

Yüksel, I., \& Dağdeviren, M. (2007). Using the Analytic Network Process (ANP) in a SWOT Analysis - A case study for a textile firm. Information Sciences, 177(16), 3364-3382. https://doi.org/10.1016/j.ins. 2007.01.001

Zakiah, Z., Saleh, A., \& Matindas, K. (2017). Gaya kepemimpinan dan perilaku komunikasi GPPT dengan kapasitas kelembagaan Sekolah Peternakan Rakyat di Kabupaten Muara Enim. Jurnal Penyuluhan, 13(2), 133. https://doi. org/10.25015/penyuluhan.v13i2.14977 